\title{
CONSUMER BEHAVIOR IN INDUSTRIAL ERA 4.0 TO AVOID MARKET FAILURE
}

\author{
TITI RAHMAWATI \\ NUR AISYAH

\begin{abstract}
Universitas Muhadi Setiabudi, Jl. Pangeran Diponegoro No.KM.2, Pesantunan, Brebes, Indonesia titirahmawati165@gmail.com
\end{abstract}

\begin{abstract}
Local governments should make policies related to market implementation that are closely related to economic aspects by focused on the orientation and behavior of consumer shopping in the industrial era 4.0. The style of shopping in the future in the era of industrial revolution 4.0 should be able to combine the style of online shop and physical shop. Both are complementary rather than replacing with regard to the concept of consumer satisfaction. This research aims to find out how much influence income redistribution, servicescape, festivalscape and experienscape have on efforts to prevent market failure. Research method with Kuantitative approach. The research sample of 200 traders in the Islamic market center Saporete Brebes obtained using Proportionate Stratified Random Sampling. The results showed that there was a weak and insignificant influence on efforts to avoid the failure of the Saporete Islamic Sunday Market Center Brebes Based on the results of multiple linear regression tests on servicescapes, experienscapes, festivalscapes and income redistribution together.
\end{abstract}

Keywords: Experienscapes, servicescapes, festivalscape, shopping experience, pasar ahad saporete brebes

Abstrak: Pemerintah daerah setempat sebaiknya membuat kebijakan terkait penyelenggaraan pasar yang berkaitan erat dengan aspek ekonomi dengan menitikberatkan pada orientasi dan prilaku berbelanja konsumen di era industri 4.0. Gaya berbelanja di masa yang akan datang pada era revolusi industri 4.0 harus mampu menggabungkan gaya online shop dan physical shop. Keduanya bersifat saling melengkapi bukan menggantikan dengan memperhatikan konsep kepuasan konsumen. Riset ini bertujuan untuk mengetahui seberapa besar pengaruh redistribusi income, servicescape, festivalscape dan experienscape pada upaya mencegah kegagalan pasar. Metode penelitian dengan pendekatan Kuantitative. Sampel penelitian berjumlah 200 orang pedagang pada pasar Islamik Center Saporete Brebes yang diperoleh dengan menggunakan Proportionate Stratified Random Sampling. Hasil penelitian menunjukan bahwa terdapat pengaruh yang lemah dan tidak signifikan terhadap upaya menghindari kegagalan Pasar Ahad Saporete Islamik Center Brebes Berdasarkan hasil uji regresi linear berganda terhadap servicescapes, experienscapes, festivalscape dan redistribusi pendapatan secara bersama -sama.

Kata kunci: Experienscapes, servicescapes, festivalscape, shopping experience, pasar ahad saporete brebes

\section{INTRODUCTION}

Individual shopping behavior is the result of consideration and influence of several factors that become important aspects in market changes and developments. The categorization of shopping styles from one perspective illustrates that consumers can use their rationale when making shopping decisions 
and some consumers rely on experiences such as taste, sensation, feelings, imagery as well as emotions as the basis for decision making. While some other consumers focus on consumer behavior contingency and the environment as a factor that is considered to greatly influence the shopping decisions of Helmi, Arifianti and Nugraeni (2018).

Understanding the style of consumer shopping is a strategy to predict the market so that not only the circulation of the market can take advantage of the information but also become the study material of policy makers in reducing the factors that trigger the emergence of market failures. Trading practices in the industrial 4.0 era integrate two styles of consumer shopping behavior, offline and online. Therefore, it is not only physical shoppers who are trying to build their network online but also online businesses who are trying to open their physical shop shop of the future (2016).

Understanding the factors that influence consumer decisions and consumer behavior itself will provide knowledge to manufacturers about strategies and communication in better marketing Siti Rosmayanti et al (2020). The decision making in question is the process of problem recognition, information search, evaluation and selection of alternative products, distribution channel selection and implementation of decisions on products to be used or purchased by Munandar consumers (2001). Thus, consumer behavior is an individual consideration after going through a good consideration process about all information about the product.

Previous research on shopping behavior by Fourie and Krugger (2015); and Villet, Moes, Schrandt (2015), focusing on exploring the dimensions of servicescapes that describe experience scapes,festival scapes, retail scapes, and museumscapes. While the research conducted by researchers focused on servicescape, experiencescape and festivalscape as independent variables. In addition, previous research has used market failures that have been done by Dorle (2018) using a MBO approach that focuses on resource utilization strategies such as differentiation, low price stratgei, market grouping, and several ways of migration.. This research is expected to provide a multidisciplinary study on understanding shopping behavior in the era of industry 4.0 in a socioeconomic perspective so that it can become information and the basis of policy making of relevant stakeholders.

Changes in consumer behavior are motivated by many factors including product quality, market conditions, price and comfort elements. Physical shop is a traditional style market that has limited opening time characteristics and limited access while online shop has unlimited open duration and tends to be low cost in its management. Both practices remain in the industrial 4.0 era and raise questions about the shortcomings and advantages of both being complementary and unable to replace each other.

\section{Physical Shop}

Buyer expectations continue to grow and change, so traders are encouraged to be able to create a shopping experience that is loved by consumers. The decision to shop at a physical shop in the digital age provides its own experience that includes cognitive, affective, social and of course responses -- physical responses directly Bustamante \& Rubio (2017). The physical shop experience is considered as a traditional style that basically has the advantage of providing stimulus to buyers to feel the journey, touch, see and feel the products directly Joonkyum and Bumsoo, in Sun and Yazdanifard (2015). Opportunities in physical shops and online shops create opportunities for businesses, both can be collaborated. So that businesses are always 
innovating and trying to integrate between online shop and physical shop.

\section{Online Shop}

The combination of lifestyle and needs is a habit that develops and merges with the times. Each individual's openness to technological innovation continues to grow. Through the online shopping system through the internet (online shop), every consumer's needs can be met easily and quickly Choi \& Park, (2015). The needs and reasons for internet use are basically diverse, based on apjii survey there are three main activities of internet use, among others, $24.7 \%$ use it for messaging communication; $18.9 \%$ use it for social media; and $11.5 \%$ use it to search for work-related information. While the use of the internet specifically to conduct online transactions (shopping for goods and services online) tends to be low on a national scale of $7.6 \%$ that is the number of consumers who shop at least once a month, when compared to the number of non-necessarily existing transactions in one month of $24 \%$. The condition is influenced by several factors, namely: (1) $18.8 \%$ of consumers prefer to buy goods directly; (2) $12.2 \%$ of consumers cannot use the app; (3) $9.5 \%$ are worried that the goods will not arrive; and (4) $9.0 \%$ are worried the goods are not up. Therefore, rill in the field of lifestyle trends online shopping is an alternative choice of consumers but not the dominant style of shopping among the public.

\section{The Future of Shopping Experience}

According to Blazquez in Irene, (2017) The traditional shopping experience is able to provide many advantages such as gifts (bonuses) as well as good service satisfaction. However, what traditional traders need to realize is the decision to revitalize physical shops that prioritize customer bound so that it can have a positive impact on the sales chart. The concept of shopping experience is defined as a still ambiguous thing that can be interpreted in several definitions, one of which is experience as an individual reaction to stimulus (Poulsson \& Kale, in Bustamanto \& Rubio 2017). Future shopping experience in industrial era 4.0 is a structured analysis of how consumer behavior in the future with changes and innovations in seller style that integrate physical shop and online shop. The discussion is then limited and defined in the concept of servicescape which is in-depth discussed in the experiencescape concept.

\section{Servicescape}

The concept of servicescape is a marketing perspective that reveals the huge influence of the physical environment for consumers and staff workers. These are physical factors that can be controlled by traders or companies that produce efforts to improve the interaction of consumers and staff employees of Villet, Anne \& Bernadette (2015). So to translate what is meant by problems, opportunities, and building efforts basically requires an integrated frame of thinking, that is what is called a servicescape. Previous research has assumed that servicescapes have an influence on consumer perceptions on the quality of goods and sales so that consumers have perfect information Villet, Anne \& Bernadette (2015). Thus, hypotheses that can be formulated as follows:

$\mathrm{H}_{1}$ : Servicescape affects efforts to prevent market failures

\section{Experiencescape}

The concept of exsperiencescape is a section that details the servicescape in an indepth explanation and focuses on the visitor experience. Exsperiencescape is a space chosen specifically by paying attention to the design created to create an experience for visitors so as to meet consumer expectations. Thus exsperiencescape influenced the occurrence of a perfect market and avoided the failure of Villet, Anne \& Bernadette (2015). 
Thus, hypotheses that can be formulated as follows:

$\mathrm{H}_{2}$ : Exsperiencescape affects efforts to prevent market failure

\section{Redistribution of income}

Three types of income redistribution, namely 1) income redistribution is defined as a means of achieving prosperity with taxes, cost payments, allocation of government expenditures referred to as ex post approach on income redistribution, so that in this approach will discuss a lot about the role of each stakeholders in the market; While approach 2) defines income redistribution as a viewpoint of ownership in the provider of goods /services compared to ownership after interaction occurs in the market, so this approach will focus more on the goal of reducing the benefit of ; $D$ an 3 ) redistribution of income is seen as focusing on classifying the market differently and not focusing on the results of the market itself, this approach is referred to as a process approach, so that this approach becomes the basis for set rules on a Dietsch market (2008). Thus, hypotheses that can be formulated as follows:

$\mathrm{H}_{3}$ : income redistribution affects efforts to prevent market failure

\section{Festivalscape}

The focus on festivalscape is an effort to increase consumer loyalty that will have an influence on rising profits, promoting business, creating business direction, increasing sales and motivating the re-selling of certain products Bowen \& Chen (2001) Enderson et al. (2000). Therefore, consumer behavior seen on the festivalscape side is very attentive to evaluation to set choices, experiences, maintain quality, pay attention to satisfaction factors, so that consumers dpat behavior including buying visits Back, willingness to give input and positive impressions by word of mouth. Thus, when the highest festivalscape level has been reached, consumer loyalty will have implications for effective marketing costs so that it can be believed to be part of efforts to avoid market failure. Hypotheses that can be formulated as follows:

$\mathrm{H}_{4}$ : income redistribution affects efforts to prevent market failure

Economic development and growth are two different things, both of which are economic factors of concern in maintaining economic stability in order to achieve prosperity and avoid market failure. Market failure is defined as the condition under which externality, asymmetric information, and production of various goods need inefficient so that the market can not produce optimal pareto, in this condition the market is considered to have failed Dietsch (2008). Revenue redistribution efforts are seen as the focus of different market classification and do not focus on the outcome of the market itself, this approach is referred to as a process approach such as manipulation efforts in the servicescape that can regulate the surrounding environment, maximize the function of space and create the desired mark or symbol. In efficiency in the production of goods in question is a social object that is often referred to as an effort to maximize social welfare that has not been realized, while the ideal market or market conditions are seen as productive markets that can produce welfare and achieve decent living standards, achieve stable conditions and can distribute information well and structured Dietsch (2008). Creating an ideal market is to define, design, and organize everything that leads to the best experience for consumers, it is an experienscape effort in reducing the benefits that might be an unfavorable experience for consumers. 


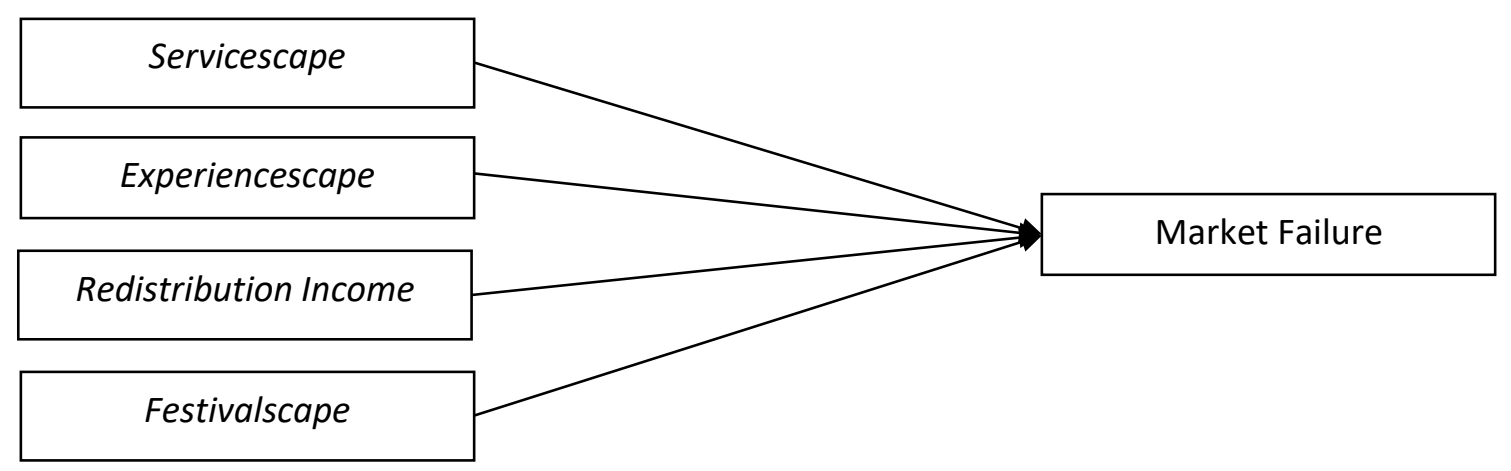

Figure 1 Research Model

\section{METHOD}

Research with quantitative approach. The sample numbered 200 buyers at the Saporete Islamik Center Brebes Sunday Market. Sample selection technique with simple random sampling. The research was conducted by measuring each variable through the matric table of the focus of research studies as follows;

Table 1 Means, standard deviations, and correlations among variables

\begin{tabular}{llcc}
\hline Variable & Mean & SD \\
\hline 1 & Servicescape & 42.88 & 3.458 \\
2 & Experiencesapes & 19.33 & 2.370 \\
3 & retribusi pendapatan & 18.66 & 1.741 \\
4 & festivalscape & 20.32 & 1.502 \\
5 & Kegagalan Pasar & 17.65 & 2.189
\end{tabular}

Note: ${ }^{*} p<.05 ;{ }^{* *} p<.01 ;{ }^{* * *} p<.001$.

Based on output in the compound correlation coefficient ( $R$ square) is 0.022 . The coefficient showed a weak correlation of $22 \%$ between servicescape, experienscape, and revenue redistribution and festivalscape to avoid market failure. Thus, the higher the value of servicescape (X1), experienscape (X2), and revenue redistribution (X3), festivalscape (X4), does not make efforts to prevent market failure the better, and conversely the lower the value of servicescape (X1), experienscape (X2), and revenue redistribution (X3), festivalscape (X4) does not make efforts to prevent market failure worse. Based on column $F$ in the ANOVA section, known $F$ calculates by 1,410 , while the price of Ftabel is 0.05 it indicates $\mathrm{HO}$ is accepted. Thus, servicescape (X1), experienscape (X2), and revenue redistribution (X3) do not have insignificant correlations and are supported by very small R2 (coefficients of determination), therefore indicating the ability of independent variables in explaining variable variations is very limited. The parts that make up the double regression equation, or

$$
\begin{gathered}
y^{\prime}=16.805(a)+0.86\left(X_{1}\right)+(-.011)\left(X_{2}\right)+ \\
(-.089)\left(X_{3}\right)+(-.047)\left(X_{4}\right)
\end{gathered}
$$

1.4/4

$A_{2}$ yalue indicates that the value $y$ is at 16.805 wh.ens $X 1$ is assumed to be equal to 0 . The value $X 1=0.86$ indicates that each change of one unit or tilapiaai unit X1 will increase one unit of $y$ value by 0.86 assuming $X 2, X 3$ and $X 4=0$. While the value $X 2=(-0.011)$ indicates that each change of one unit or the value of unit X2 will decrease one unit of $y$ value by -0.011 assuming $X 1, X 3$ and $X 4=0$. Furthermore, the value $X 3=$ -0.089 indicates that each change of one unit or unit value of $X 3$ will decrease one unit of $y$ value by -0.089 assuming $X 1, X 2$ and $X 4=0$.

Consumers in the future will experience changes in behavior in the process of buying and selling, skenerio formed is a process of adding value oriented to economic collaboration. The collaboration in question is the behavior of consumers who prioritize easy access to the services and goods they need, but do not have 
to have it but rather make use of it at a certain time when they need Dietsch (2008). Therefore, there is a significant change in the orientation of consumers who not only focus on experience and products but also consider the scope of value with how the products and services are displayed online or directly in the physical shop that can in detail reveal the relationship between needs, benefits and time. Thus, consumers have a very important role in every activity and implementation of the market, it happens because consumers can be the subject and object at the same time so that the behavior or orientation of consumers in the future becomes an integrated part in the success of the implementation of a market. But the consumer's point of view is a partial part, in order to make it a complete frame of thought is to correlate the point of meeting servicescapes between consumers and dietsch services (2008).

The shopping experience obtained by consumers is the interaction of the process of organizing the market where consumers feel both physically and satisfaction of inner value. The shopping experience becomes more important because the experiencescapes dimension is a specific space chosen, designed, and arranged for the purposes of creating, supporting and being a guide to a Dietsch experience (2008). An interesting experience in organizing The Saporete Brebes Sunday Market for example, which is known as the market title every Sunday morning which is always associated with unusual market titles. Consumers individually or collectively with family can find not only products that they may need but also government services such as vehicle tax payments, population services from the Department of Population and Civil Registration as well as health services such as blood donation events along with free health checks. Several factors that make up the experience are identified into the festivalscape which is an influential aspect of satisfaction and loyalty in a Fourie \& Kruger market, (2015). Thus, customer satisfaction and loyalty can be measured in the success of market implementation.

\section{RESULT}

\section{The influence of service scapes in an effort to avoid market failure}

Knowing how consumers drop their choices on a product and making the decision to return to the same place is a comprehensive marketing perspective covering several aspects such as translating expectations, mood, conditions, and consumer orientation Villet et all (2017). The frame of thought on the concept of servicescapes is basically trying to take the point of view of the services provided to consumers so that physically consumers can get the products and services they need. This good reception was termed by Bitner (1992) as perceived servicescape. The effect of servicescapes on consumer reaction in the implementation of the market is divided into three subdimensionals including: 1) physical environment that includes surrounding conditions, functions / spaces, signs and symbols; 2) internal responses that include cognitive, emotional, and physicological aspects; 3) personal characters that include approach/avoidance, and social interaction of Villet et all (2017). Several sub-dimensions in the concept of servicescapes explain the condition of The Sunday Market Saporete Brebes is in good condition, it can be seen from the results of the study that explained that from 200 respondents the average value of the answer was at 42.88. Thus, the physical environment, internal response and personal character of consumers in the Saporete Brebes Sunday Market are in a good category but not yet high enough and significant.

Test results on servicescapes variables in the study showed that servicescapes exerted a weak and insignificant influence with a positive direction of 0.086 with a significance of $P=0.000$ $(P<0.05)$. Thus, it can be concluded that servicescapes variables partially influence 
efforts to avoid market failures. That is, if the servicescapes variable $(\mathrm{X} 1)$ is increased by 1 unit while the other variable remains (constant) then it will be followed by an increase in the success of the Saporete Brebes Sunday Market by 0.085 units.

\section{The influence of experience scapes in an effort to avoid market failure}

The consumer experience when visiting a market gives its own impression, these conditions make the implementation of the market try to focus on the appearance of a pleasant market not only emphasizes on the efficiency and effectiveness of the service but also how to create a different experience (Villet et all, 2017: 31). Experience is basically formed and closely related to the environment in which the market itself is held, so that services in the market held online or in physical stores will never be the same Shankar, et al (2010). The impression that arises naturally illustrates how satisfied and loyal consumers are to the implementation of the market, therefore the quality of facilities, the quality of programs and the quality of entertainment influences according to Cole \& Chancellor (2009); Fourie \& Kruger (2015) is directly and indirectly a factor influencing the level of satisfaction, experience and consumer attention termed as a subdymptive called festivalscape. Living the festivalscape in the implementation of the market means animating the atmosphere such as The Sunday Market Saporete Brebes which always opens its market title with healthy gymnastics Together accompanied by music with pop and dangdut nuances (local culture), even several times held healthy street events held in the area of Pasar Ahad Saporete Brebes facilitated with various interesting prizes. This received a good response so as to provide motivation for consumers to continue to be in the Saporete Brebes Sunday Market every week when the event arrives. The results of the study explained that out of 200 respondents the average number of answers was at 19.33 .
Experiencescapes variables partially exert a weak and insignificant influence on efforts to prevent market failure. That is, if the experiencescapes variable (X2) is increased by 1 unit while the other variable remains (constant) then it will be followed by an increase in efforts to prevent market failure of -0.011 units. This is due to several factors, namely the creativity of each trader still needs to be improved, such as variations in merchandise and discount programs or discounts that are usually in great demand by consumers because basically traders are the focus of consumer attention on the title Of Sunday Market Saporete Brebes. The next thing to be improved is public facilities such as clean and free bathrooms because so far the use of bathrooms is managed on a paid basis and not strategic enough from the central area of keramian and parking space that is quite limited to the Saporete Brebes Sunday Market.

\section{Effect of income redistribution in an effort to avoid market failure}

Market failure is an inherent gap in the concept of economic well-being in the neoclassical era, firstly market failure assumes that failure occurs due to scarcity of resources, and the second assumption that the market is in imperfect condition so that the government is dinggap need to intervene in fixing it (Simon, 2012: 2). The problem involves both consumers as subjects and objects at the same time as well as the government as a political elite that always strives to maintain public trust, so that the right collaboration between the two in theory moves towards the realization of optimal Pareto legal conditions. The next step in dealing with market failure can basically be taken through economic measures such as income redistribution which is understood as the state's efforts in maximizing the welfare of the community, which can be classified in three approaches namely ex post, ex ante, and dietsch process (2008). These three approaches try to understand market failure in the viewpoint of ecenomis and political philosophy. Both briefly viewed market failure as 
a condition of inefficcient so that optimal pareto conditions could not be achieved and a condition of injustice arising from market activities itself. Thus, income redistribution efforts are one of the alternative solutions that can be taken in the face of market failure. However, the effect of redistribution on efforts to avoid market failure has not been high enough.

The variable partial redistribution of revenues exerts a very small influence on efforts to avoid market failures in the implementation of the Saporete Islamic Center Brebes Sunday Market. That is, that if the variable redistribution of revenue (X3) is increased by 1 unit while other variables remain (constant) then it will be followed by an increase in the success of the implementation of the Saporete Brebes Sunday Market by $(-0.89)$ units. This is due to the weakness of Saporete Brebes Sunday Market lies in the levy imposed both to traders and consumers. Retribution to traders is the management of the organizing committee to be further distributed as a hygiene fund, and security while the levy imposed on consumers is the cost of parking and the use of public facilities so that in its management formed the Association of Islamic Traders Centre (PPIC). The revenue levy is still intended for internal activities while the levy is not allocated up to official taxes to local authorities so there has been no significant impact on government revenues through the Sunday market title of the Brebes Islamic Center.

\section{The influence of festival scape in an effort to avoid market failure}

Understanding consumer behavior is part and all about creating an ideal market that is loved. Not only about product variation, location and market conditions but no less important is formulating how consumers can come back and become so loyal such as spreading positive impressions by word of mouth and giving recommendations to others. PAS ICB visitors experienced insignificant ups and downs, making it difficult for researchers to determine specific reasons for visitors coming back to PAS ICB.

Festivalscape variables partially give a negative influence that is $(-0.047)$ units on efforts to avoid market failures in the implementation of the Saporete Islamik Center Brebes Sunday Market.

Focusing on the future shopping experience in industrial era 4.0 is a structured analysis of how consumer behavior in the future with changes and innovations in the style of sellers who integrate physical shop and online shop. The results of the Indonesian Association of Internet Service Providers (APJII) survey released that there has been a significant increase in internet user penetration since 20172018 growth of 27,916,716. Graph of the increase if classified from the type of urban and rural areas then internet access has exceeded both urban areas with a comparison of internet users by $74.1 \%$ and non-internet users $25.9 \%$ while rural areas are at $61.6 \%$ as internet users and $38.4 \%$ as non-internet users. Thus, in the future either online trading or trading on physical stores will not tone the boundary between the two . virtual form that drives the expectations of every consumer in the simulation of real forms will be present in every online trade while virtual depictions on products to attract the imagination of consumers will be present in physical stores. However, if it refers to the change in overall aspects, there will be innovations in certain aspects such as, service, technology, organization, and finance as the overall characteristics of future shopping experience in the future Villet et all (2017).

The results of research on the influence of service scape $(X 1)$, experience scapes (X2) and revenue redistribution (X3) as dimensions in the future shopping experience together on the success of the Saporete Brebes Sunday Market were categorized weakly with a positive direction of 0.006 with a significance level of $P=0.000(P$ $<0.05$ ) or equivalent to $6 \%$. That is, that if the servicescape variables (X1), experiencescapes 
(X2) and revenue redistribution (X3) are jointly increased by 1 unit while the other variables remain (constant) then there will be an increase in the success of the Saporete Brebes Sunday Market by 0.006 units. The influence simultaneously and together the two variables give an insignificant magnitude, the condition is in accordance with several aspects that can be improved and improved so as to produce several positive points including Villet et all (2017) the creation of harmonization, where there is a conformity between the environment, strategic areas, product variation, price and good quality and a sufficient amount to the needs of consumers; 2) avoid negative reactions of consumers to the shopping experience by paying attention to the cleanliness and comfort of the environment, easy-to-reach access, and adequate parking areas; 3 ) to be more innovative in creating different experiences on visual aspects such as the presence of music, good smells and interesting events; 4) increase differentiation by attracting consumer attention such as presenting promo programs and integrating public services 24 hours so that consumers feel comfortable and gain a lot of convenience. Thus, both variables can simultaneously support the successful implementation of Saporete Brebes Sunday Market.

The paradigm of market failure on the other hand is a form of failure of the government in providing public policies to optimize the economic function for the lives of people Dollery \& Wallis (2001). Understanding the market failure in question positions the government as a rule-maker on the overall economic market. The implementation of Saporete Brebes Sunday Market, for example, was initiated by the Office of Cooperatives and Micro And Medium Enterprises (MSMEs) and established on government land managed by yayasan Islamik Centre independently. However, in its implementation the levy imposed on both traders and buyers as consumers is not necessarily deposited by the organizing committee but is only used as an operational cost of organizing the Saporete Brebes Sunday Market, so there is no transfer payment which is an accumulation of revenue receipts one year ago. The government's position as initiator as well as being part of the board of management of The Sunday Market Saporete Brebes also still has a special budgeting given to the organizing committee as electricity and hygiene costs if it holds events such as public services in the Saporete Brebes Sunday Market. However, the unfortunate thing is that the local government does not have a specific regulation that regulates the implementation of The Sunday Market Saporete Brebes so that in its management the organizing committee refers only to the board meeting of the Central Islamic Foundation of Brebes which often produces decisions that do not reflect the fairness, efficiency and effectiveness of the implementation of the Saporete Brebes Sunday Market. Income levy is an effort to avoid market failure thus not enough to be a tool for local governments in the implementation of Saporete Brebes Sunday Market.

\section{CONCLUSION}

There is a weak and insignificant influence with a positive direction between servicescapes and efforts to avoid market failures in the implementation of Saporete Brebes Sunday Market.. Recommendations through servicescapes is to strengthen the coordination of ICB PAS management with stakeholders so that the physical environment, internal response and good merchant character so that the interaction of buying and selling meets ideal conditions.

There is a weak and insignificant influence with a negative direction between experienscapes and efforts to avoid market failures in the implementation of the Saporete Brebes Sunday Market. Recommendations through experiencescapes is to build the creativity of traders in peddling their products so that consumers have an interest in the products offered 
such as new product promos, discounts and product model variations.

There is a weak and insignificant influence with a positive direction between income redistribution and efforts to avoid market failures in the implementation of Saporete Brebes Sunday Market. Recommendations through the redistribution of income in the future is to register all traders in order to take care of business licenses so that the contribution of traders can be more real to the local government; and management of dues in a transparent and accountable manner so as to maximize its allocation so as to provide benefits directly to the board, merchant members and also local governments.

There is a weak and insignificant influence with a negative direction between the festivalscape and efforts to avoid market failure at the Saporete
Brebes Sunday Market. Recommendations through festifalscape in the future will be to keep the price and quality of goods in accordance with what the consumer wants so that loyalty to consumers can be created well.

Based on the results of multiple linear regression tests on servicescapes, experienscapes and income redistribution jointly obtained a conclusion that there is a weak and insignificant influence on efforts to avoid the failure of the Sunday Market Saporete Islamic Center Brebes. The results of this research are used as inputs for local governments in the basis of policy making related to the implementation of markets that are closely related to economic aspects and focus on the orientation and style of consumer shopping in the industrial era 4.0.

\section{REFERENCES:}

Bustamante, J. C., \& Rubio, N. 2017. Measuring customer experience in physical retail environments. Journal of Service Management.

Choi, S. A., \& Park, J. W. 2015. Investigating the effect of online service quality of internet duty-free shops on trust and behavioral intention. Journal of Airline and Airport Management, 5(2), 101-115.

Cole, S. T., \& Illum, S. F. 2006. Examining the mediating role of festival visitors' satisfaction in the relationship between service quality and behavioral intentions. Journal of Vacation Marketing, 12(2), 160-173.

Dietsch, P. 2008. Does market failure justify redistribution?

Dollery, B., \& Wallis, J. 2001. The theory of market failure and policy making in contemporary local government. University of New England, School of Economic Studies.

Dorle, N. 2016. THE IMPORTANCE OF STRATEGIES IN THE SALE PROCESS. Challenges of the Knowledge Society, 739.

Fourie, Monique dan Martinette Kruger. 2015. "Festivalscape Factors Influencing Visitors Loyalty to an Agri-Festival in South Africa". Journal of Open Journals. 3

Guerin, Bernard. 2020. From "Behavior \& Philosophy" to "The Behavior of Philosophers". University of South Australia.

Helmi, A. R., Arifianti, R., \& Nugraeni, W. 2018. Shopping Style: Comparison of Indonesian and Malaysian Customer. AdBispreneur: Jurnal Pemikiran Dan Penelitian Administrasi Bisnis Dan Kewirausahaan, 3(2), 31-37.

Keech, W. R., Munger, M. C., \& Simon, C. 2012. Market failure and government failure. In Paper submitted for presentation to Public Choice World Congress (1-43).

Kharismar, Emir dan Stella. 2014. The Influence of Collateralized Assets, Profitability, Income Tax, Non-Debt Tax Shield, Firm Size and Growth on Capital Structure. Jurnal Bisnis dan Akuntansi, 16(2), 114-122

Lee, J., \& Kim, B. 2014. Assortment optimization under consumer choice behavior in online retailing. Management Science and Financial Engineering, 20(2), 27-31.

Nuraini, Febritesna, et al. 2020. Strategy for Living Labors in Industrial Era 4.0. Proceedings of the $6^{\text {th }}$ International Conference on Education and Technology (ICET 2020), 501 
Nurdayadi, Rocky Alfian Bunaca. 2019. The Impact of Deferred Tax Expense and Tax Planning Toward Earnings Management and Profitability. Jurnal Bisnis dan Akuntansi, 21(2), 215-236

Setiawan, Arif Agus. (2016). Analisis Prilaku Konsumen terkait Tiga Website. Universitas Pembangunan Jaya.

Simon, Carl, William R. Keech \& Michael C. Munger. 2012. "Market Failure and Government Failure". Present in Public Choice World Congress, Miami. 2

Sudirman, Acai et al. (2020). Prilaku Konsumen dan Perkembangannya Di Era Digital. Bandung: Widina Bhakti Persada.

Sugiyono, P. 2016. Metode Penelitian Manajemen(Pendekatan Kuantitatif, Kualitatif, Kombinasi (Mixed Methods), Penelitian Tindakan (Action Research, dan Penelitian Evaluasi).

Sumarwan, Ujang. 2016. Perilaku Konsumen: Teori dan Penerapannya dalam Pemasaran. Jakarta: PT Ghalia Indonesia.

Van Vliet, H., Moes, A., \& Schrandt, B. 2015. The fashion retailscape: innovations in shopping.

Yustine, Maris Agung Triandewo. 2019. Pengaruh Kualitas Layanan, Citra Perusahaan dan Kepercayaan pada Loyalitas Konsumen. Jurnal Bisnis dan Akuntansi, 22(1), 13-24. 
